\title{
A Case Study of Campus-Based Initiatives to Disaster Awareness Program: The Road to Resilience
}

\author{
Vivien How ${ }^{*}$, Pamela Jude Peter ${ }^{2}$, Kenny Brian Martinus², Norjihan Bt. Mohd Dzahir², \\ Ain Izzati Bt. Ali², Nur Deena Adzlynn Bt. Ahmad Dzahiruddin², \\ Mohd Fikri Bin Zainal Aripin² \\ ${ }^{1}$ Department of Environmental and Occupational Health, Faculty of Medicine and Health Sciences, Universiti \\ Putra Malaysia, Serdang, Malaysia \\ ${ }^{2}$ Faculty of Safety and Health, Cyberjaya University College of Medical Sciences, Cyberjaya, Malaysia \\ Email: *vivien@upm.edu.my
}

Received 22 September 2015; accepted 8 October 2015; published 14 October 2015

Copyright (C) 2015 by authors and OALib.

This work is licensed under the Creative Commons Attribution International License (CC BY).

http://creativecommons.org/licenses/by/4.0/

(c) (i) Open Access

\section{Abstract}

Introduction: The Hyogo Framework for Action (HFA) to build the resilience of nations and communities to disasters has been proposed since year 2005. Even though educational based disaster risk reduction programs have been conducted by the institutional agencies for years, communities are still weak in response to disaster preparedness. The current efforts need to be revised to understand the possible dilemma of moving the community from fragility to resilience. Objective: To examine the community perception of the disaster preparedness and response, and their readiness to become the resilient community. Methodology: This is a case-study conducted among 40 participants at the age of 18 - 29 years from a local private college. A campus-based disaster awareness seminar was initiated into a strategized learning framework to facilitate knowledge transfer and foster awareness built among the participants. The program framework consists of three sections: 1) to expose the participant with information on visual-aid and interactive discussion; 2) to involve the public involvement in hands-on practice bandages and dressings; 3 ) to evaluate the public's readiness and acceptance towards a resilience nation based on a survey questionnaire. Result: $\mathbf{7 5 \%}$ of the educated respondents claimed that they did not consider themselves as the resilient group of the disaster, and $55 \%$ referred to the non-validated news from internet/ social media as the source to gather information. Nevertheless, most of the participants have expressed common expectations, such that 1) to share experiences and knowledge about disaster risk reduction planning and response; 2) to learn how to empower the local community during disasters. Conclusion: It is truth that urban and educated groups are fragile in response to the disaster. Nonetheless, knowledge transfer is one of the most feasible approaches to building a resi-

${ }^{*}$ Corresponding author. 
lient community and fostering a nation who is able to withstand and recover from any upcoming disaster with sustainable development.

\title{
Keywords
}

\author{
Campus, Disaster, Risk Reduction, Awareness, Resilient Community
}

\author{
Subject Areas: Education, Public Health
}

\section{Introduction}

In 2005, The World Conference on Disaster Reduction proposed the Hyogo Framework for Action (HFA) proposed the 10-year (2005-2015) plans which targeted to build a resilience of nations and communities to disasters. The first plan is to explain, describe and detail the work that is required from all different sectors and actors to reduce disaster losses [1]. According to Malaysia's National Progress Report [2], the educational-based disaster risk reduction programs have been implemented across the country, such as:

- Safe School Program: UNICEF and MERCY Malaysia in collaborate with governments to implement School Preparedness program to train the students and teachers in disaster preparedness [3].

- Smart Support Team: UNICEF and MERCY Malaysia collaborate with the Ministry of Education, which complements the welfare services of the Ministry of Women, Family and Community Development and National Security Council, to empower schoolteachers to respond to children who are faced with disaster relief and rehabilitation [3].

- School Watching Workshop: MERCY Malaysia introduced a "Community-Based Hazard Mapping” tool to at least 10 provinces in the country which help school communities to identify hazards and risks in and around the schools and devising solutions to make it a safer place [4].

- Community-Based Disaster Risk Management: Malaysia's National Security Council (NSC) and Asian Disaster Reduction Center (ADRC) conducted community-based disaster risk management workshop. This workshop is to strengthen disaster resilience among the local government officials who may direct or indirectly involves to disaster management [5].

- NGO Training for Disaster Risk Reduction: Malaysia NGO, e.g. MERCY Malaysia, Malaysian Red Crescent, Compassion Relief Tzu Chi Foundation, etc. has conducted frequented training in disaster risk reduction programs by their respective institution [5].

Malaysia was known as one of the natural disaster free zones which she is freed from earthquake, volcanoes, typhoon, etc. However, recent records show that there is an increasing of catastrophic damage due to unexpected hits. On 5 June 2015, an earthquake struck Ranau, the state of Borneo Sabah, with a moment magnitude of 6.0. It is confirmed that 18 people have killed in rock falls on Mount Kinabalu. This earthquake was the strongest to affect Malaysia since 1976 [6]. Even though climate change is an inevitable evolution process happen to its nature, past study [7] shows that the effect of abrupt climate change on seasonal monsoon in Asia has left an unexpected impact on the variability of monsoon rainfall in Southeast Asia. For instances, on 15 December 2014-3 January 2015, more than 200,000 community from the states of Kelantan, Terengganu, Pahang and Perak were affected due to the unexpected heavy rainfall. This has caused the widespread of flooding in east coast of Peninsular Malaysia [8]. On 11 August 2015, flash flood hit Puncak Alam town where the water rose up to a meter high. The rising flood waters forced at least 20 toddlers and 5 female teachers had to be evacuated by the rescue team [9].

The question arises as to how ready the Malaysian prepares in response to coping with next natural disaster, and becoming a resilient community. In fact, efforts are needed to understand the possible dilemmas which impede the community to move from fragility to resilience. The purpose of this study is to promote disaster risk reduction and foster readiness to emergency response and adaptation through the strategized knowledge-transfer approach among campus students. Therefore, the objective of this case study is to examine the community perception of the disaster preparedness and response, and their readiness to become the resilient community. 


\section{Methodology}

This campus-based disaster awareness seminar was conducted at one private college. A total of 40 students from medical and health sciences backgrounds were recruited randomly during the awareness program. As shown in Figure 1, a strategized of communication with college students was planned to ensure key message dissemination. This learning framework is designed to facilitate knowledge transfer and foster deep and strategic learning to the students by considering the following elements.

- Marincioni (2007) encouraged the use of information technology (IT) to enhance communication and abet information and knowledge exchange [10].

- Preston (2012) argues that a diversity of education materials shall be prepared to facilitate community-based education, such as leaflets, film, popular culture, written media, radio broadcasting, school curricula, family and community learning, internet and cell phone messaging, and etc. [11].

The first part emphasized on describing the influences of perceived threat and efficacy on willingness to respond during natural emergencies. Difference communication materials (e.g. video-clips, slideshow and poster interactive) were prepared which carry key messages on disaster risk reduction. This section is to sustain public engagement, promote critical thinking and trigger transformative learning.

The second part focused on hands-on demonstrating the basic bandages and dressings with the public. At this section, researchers engaged public to involve in hands-on basic bandages and dressings. This is to foster the positive and adaptive learning climate which needed to develop a resilient community.

The third part was to evaluate the student's resilience level in response to natural disaster preparedness by examining their feedback on the readiness and willingness level through the survey questionnaire.

\section{Result}

A total of 40 students at the age of 18 to 29 year old from a private college were randomly recruited to participate in this case study. $58 \%$ of them are female and $42 \%$ are male. These respondents were originated from different provinces of Malaysia, such that, Negeri Sembilan (8\%), Kuala Lumpur (5\%), Selangor (23\%), Perak (8\%), Kelantan (10\%), Johor (8\%), Sarawak (13\%), Sabah (15\%), Perlis (8\%), Perak (5\%). As show in Table 1, most of the (70\%) respondents have never experienced disaster before. Even though $30 \%$ of the respondents claimed to experience disaster (landslide and flood) before, only $25 \%$ of these respondents considered themselves as well prepared for any upcoming disasters. In fact, only $8 \%$ of these respondents rated themselves as well prepared for disaster, others claimed that they are not at all prepared (30\%), somewhere prepared (45\%), or adequately prepared (18\%).

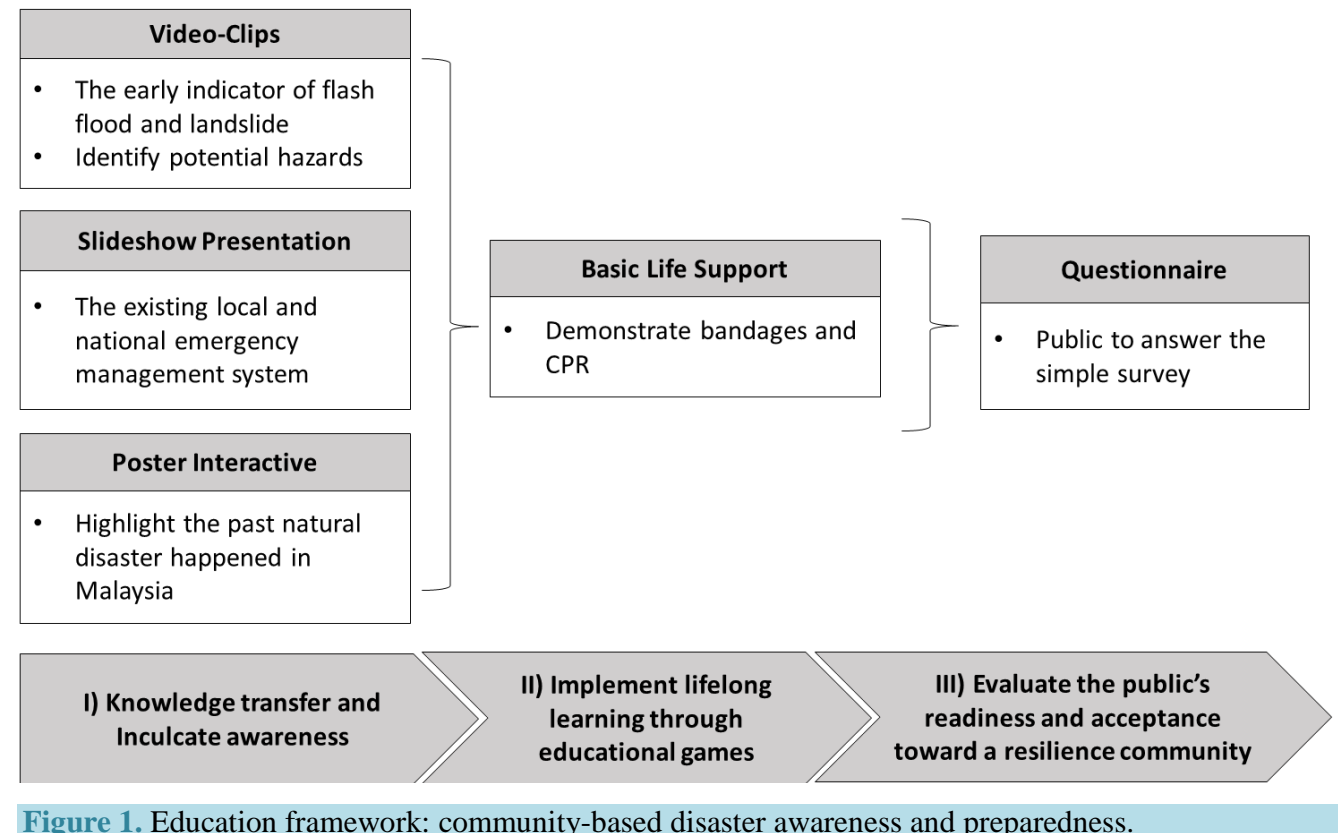

Figure 1. Education framework: community-based disaster awareness and preparedness. 
Figure 2 summarizes the sources where the respondents learn about disaster preparedness and response. Since the respondents are mostly in their 18 - 29 years of age, access to internet is among the most (55\%) widely accepted and convenience channels to expose themselves to updated info. Others such as referring to National Emergency Management or local news (TV and radio) are not widely been practiced by the young adults, some claimed that they do not know which reliable webpage portals should they follow to update the climate forecast or disaster preparedness action.

During the interactive session, we asked the respondents to suggest for the most possible and feasible action to be taken to minimize the potential damage during any upcoming disaster. Table 2 summarizes the recommendation provided by the respondents. Majority of the respondents suggest to retrofitting of educational buildings among our community. In fact, $73 \%$ suggest initiating school-based education programs, $88 \%$ agree to engage the community for participation and commitment. In order to foster dialogue and mutual understanding, $55 \%$ of respondents suggest involving the institutional support from different governmental agencies during community participatory approaches, resource empowerment or disaster management. Besides, $25 \%$ of respondents recommend using local media as the platform for information dissemination while $38 \%$ of them suggest

Table 1. Summarize the experience of disaster among respondents.

\begin{tabular}{|c|c|c|}
\hline \multicolumn{2}{|l|}{ Items } & \multirow{2}{*}{$\begin{array}{l}\mathbf{N}(\mathbf{\%}) \\
12(30)\end{array}$} \\
\hline Have you experienced disaster in Malaysia? & Yes & \\
\hline & No & $28(70)$ \\
\hline \multirow[t]{2}{*}{ Do you considered yourself as well prepared for the disaster? } & Yes & $10(25)$ \\
\hline & No & $30(75)$ \\
\hline \multirow[t]{5}{*}{ How do you rate your preparedness level? } & Not at all prepared & $12(30)$ \\
\hline & Somewhere prepared & $18(45)$ \\
\hline & Adequately prepared & $7(18)$ \\
\hline & Well prepared & $2(5)$ \\
\hline & Very well prepared & $1(3)$ \\
\hline
\end{tabular}

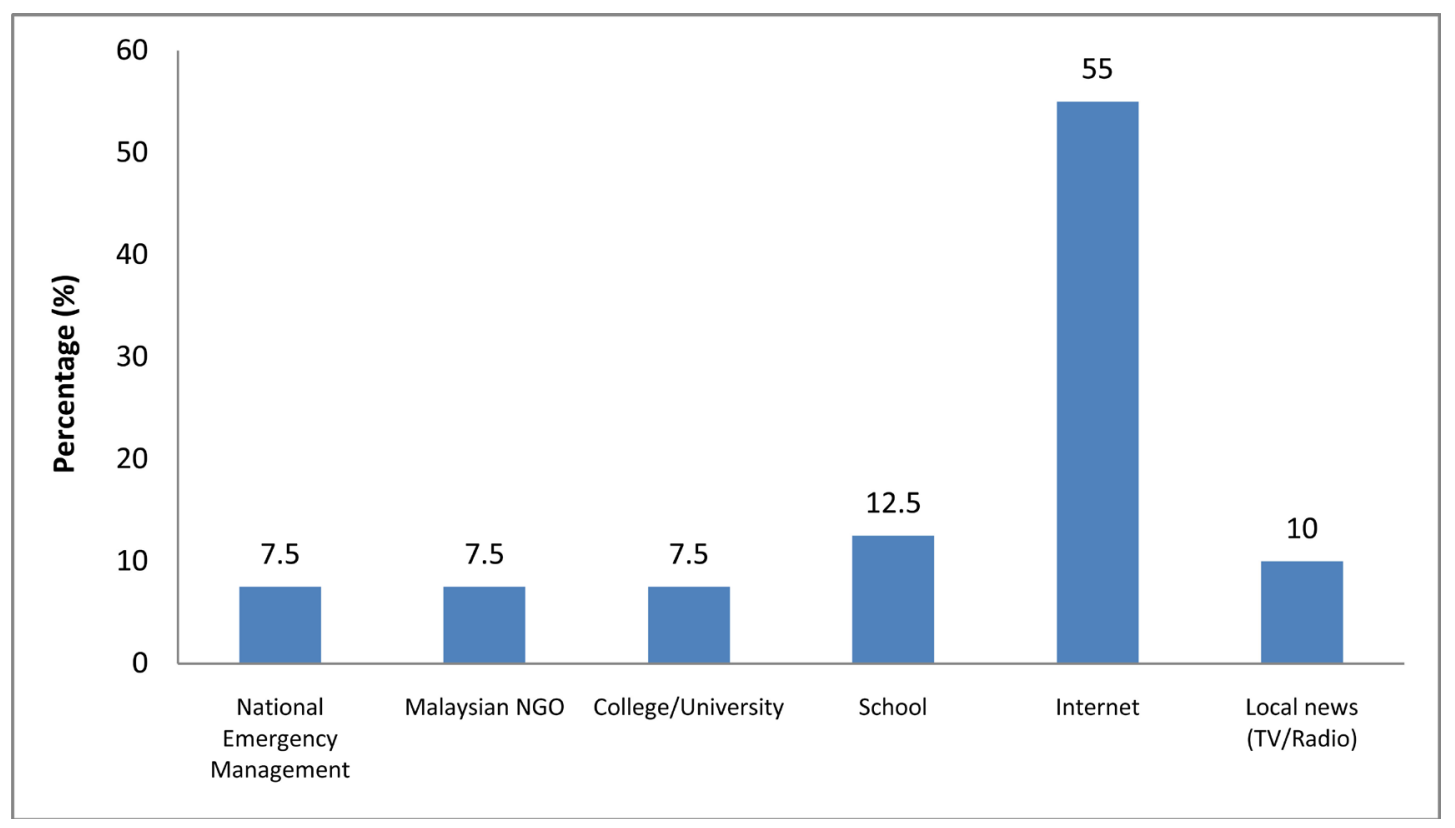

Figure 2. The sources where the respondents learn about disaster preparedness and response. 
Table 2. The recommendation provided by the respondents during interactive session.

\begin{tabular}{ccc}
\hline Recommendations & N (\%) \\
\hline School-based disaster risk education program among students at different levels & 29 (73) \\
Community-based disaster risk education program among local community (at risk) & 35 (88) \\
Enhance science and technology to improve disaster management & 15 (38) \\
Use local media as the platform for information dissemination & 10 (25) \\
Involve the institutional support to foster dialogue and mutual understanding & 22 (55) \\
\hline
\end{tabular}

enhancing the science and technology innovation for disaster management, such as improving flood early warning and monitoring system, seismic surveillance networks, and etc.

Overall, most of the participants have expressed common expectations, such that 1) to share experiences and knowledge about disaster risk reduction planning and response; 2) to learn how to empower the local community during disasters.

\section{Discussion}

Malaysian has long been taught that, their strategized geographical location protects the country from major natural disasters. It is located on a seismically stable plate that minimizes the direct effect of earthquakes and volcanoes, protected from tsunamis by surrounding landmasses, less likely to be hit by typhoons as it is located outside the tropical cyclone basins [12]. Nevertheless, climate change due to global warming has caused subtle changes in the country's climate activity and worsen the (health, property and economic) consequences which the country never encounters before with the past 20 years.

In order to achieve a safe and resilient community, it is crucial to recognize the importance of human health and well-being and their knowledge and awareness to be able to prepare, prevent, respond and recover from post-traumatic stress [13]. The survey of this study shows that, campus students are more aware of the natural disaster happened in the country and at the mode of haunting the right knowledge. Even though campus students are keen to know in-depth of the natural disaster preparatory, response and recovery management system, there are no proper platform for them to improve their adaptive capacity for the impending effects of climate change.

In view of this, Hee (2004) [14] also claimed that the program of disaster risks reduction programs among education institutions was usually impeded due to the limited ability of the school to solve safety issues without families and community support, lack of collaboration and co-operator on safety and health capacity building between the family, society and educational institution, and general lack of attention to school safety issues [15]. Nevertheless, past study [16] showed that research and academic institutions are respected by the communities as an ideal position to provide the leadership to promote disaster awareness and disaster risk reduction program by implementing the community-based disaster risk reduction activities. In other words, the local communities have high reliance on the young adults. The young adults who completed from higher institutions will be presumed as the future leader who is empowered with knowledge and skills and could develop the community's leadership capability, at the same time, strengthen their capacities to contribute to development initiatives.

Some of the respondents in this study also highlighted the role of science and technology in disaster reduction is of priority importance as compared to education initiative, such as improve seismic surveillance networks, tsunami early warning and monitoring, or flood forecasting and warning capabilities. While it is importance to apply the scientific knowledge and technical know-how [17], it is not surprise to know that many Malaysian are still unaware of the existing warning system which the government currently applies nation-wide. Table 3 summarizes some of the existing warning system which is freely accessible by the public through media and network.

Since there is the community is not well aware on these existing disaster management systems which were widely implemented by policy makers, it is crucial to reach the community with the right information on alternative channels, i.e. the educational initiative. Knowledge is merely the hidden power, for this power to be executed; the knowledge should be applied by individuals, and the community. The community-based disaster risks reduction programs should be implemented not only to the children school but also to the young adults at the campus (university or college). This could help to improve and accelerate the community capacity building, awareness raising and establish models of community or education institutions. 
Table 3. The existing warning system available in Malaysia.

\begin{tabular}{|c|c|c|}
\hline Portal & Information provided & Webpage \\
\hline Disaster portal & $\begin{array}{l}\text { - } \quad \text { Weather warning } \\
\text { - } \quad \text { Flood, haze, storm, landslide incident }\end{array}$ & $\underline{\text { http://portalbencana.mkn.gov.my/Portal/ }}$ \\
\hline Flood information & $\begin{array}{l}\text { - } \quad \text { River and rainfall alarm, highland storm advisory } \\
\text { - } \quad \text { Landslide risk area, drought area, river and water level }\end{array}$ & $\begin{array}{l}\text { http://infobanjir.water.gov.my/ } \\
\text { (Department of Irrigation and Drainage Malaysia, } \\
\text { Ministry of Natural Resources and Environment) }\end{array}$ \\
\hline $\begin{array}{l}\text { Weather and } \\
\text { climate forecast }\end{array}$ & $\begin{array}{l}\text { - Weather warnings (earthquake/tsunami), strong winds } \\
\text { \& rough seas, heavy rain and tropical cyclone \& storm } \\
\text { - Climate change monitoring }\end{array}$ & $\begin{array}{l}\text { http://www.met.gov.my/ } \\
\text { (Malaysian Meteorological Department, Ministry of } \\
\text { Science, Technology and Innovation) }\end{array}$ \\
\hline $\begin{array}{l}\text { Air pollution } \\
\text { index }\end{array}$ & $\begin{array}{l}\text { - } \quad \text { Update Air Pollution Index (API) } \\
\text { - National/local haze map }\end{array}$ & $\begin{array}{l}\text { http://apims.doe.gov.my/v2/ } \\
\text { (Department of Environment Malaysia, Ministry of } \\
\text { Natural Resources and Environment) }\end{array}$ \\
\hline Public works & $\begin{array}{l}\text { Public works services during type of disaster, e.g. } \\
\text { building collapse, flood, landslide, etc. }\end{array}$ & $\begin{array}{l}\frac{\text { http://bencanaalam.jkr.gov.my/v2/ }}{\text { (Public Works Department, Ministry of Works }} \\
\text { Malaysia) }\end{array}$ \\
\hline
\end{tabular}

\section{Conclusion}

In conclusion, this case-study shows that Malaysian is getting more aware on the necessary of preparing themselves for any upcoming natural or manmade disaster. In view of this, educational institutions are the center of communications to disseminate the lifelong learning knowledge. Knowledge transfer via different modes of educational approaches is among the most possible and feasible manners to promote the resilient communities and foster a nation whom is able to withstand and recover from any upcoming disaster with sustainable development. Therefore, the proposed working framework of educational based (community or students) risks reduction programs in this study is suitable to be applied to both the community and school children.

\section{References}

[1] (2007) Hyogo Framework for Action 2005-2015: Building the Resilience of Nations and Communities to Disasters. Extract from the Final Report of the World Conference on Disaster Reduction (A/CONF.206/6). United Nations International Strategy for Disaster Reduction (ISDR), Geneva.

http://www.unisdr.org/files/1037 hyogoframeworkforactionenglish.pdf

[2] (2012) (Malaysia) National Progress Report on the Implementation of the Hyogo Framework for Action (20112013) - Interim. The United Nations Office for Disaster Risk Reduction, Geneva. http://www.preventionweb.net/files/28824_mys_NationalHFAprogress_2011-13.pdf

[3] Izumi, T. and Shaw, R. (2014) Civil Society Organization and Disaster Risk Reduction: The Asian Dilemma. Chapter 7: Civil Society and Knowledge, Education and Training in Risk Reduction. Springer, Tokyo.

[4] Disaster Risk Reduction (DRR) (2015) MERCY Malaysia. http://www.mercy.org.my/0910060509\%C2\%BBDisaster_Risk_Reduction_(DRR).aspx

[5] (2015) The Country Activity Report from Asian Disaster Reduction Center (ADRC). http://www.adrc.asia/adrcreport_e/archives/area-country/malaysia/

[6] (2015) Sabah Quake Strongest to Hit Malaysia since 1976. The Malaysian Insider. http://www.themalaysianinsider.com/malaysia/article/sabah-quake-strongest-to-hit-malaysia-since-1976

[7] Loo, Y.Y., Billa, L. and Singh, A. (2014) Effect of Climate Change on Seasonal Monsoon in Asia and Its Impact on the Variability of Monsoon Rainfall in Southeast Asia. Geoscience Frontiers. http://dx.doi.org/10.1016/j.gsf.2014.02.009

[8] (2014) Rising Flood Waters Force More People to Flee Homes in East Coast of Semenanjung Malaysia. The Borneo Post.

http://www.theborneopost.com/2014/12/23/rising-flood-waters-force-more-people-to-flee-homes-in-east-coast-of-seme nanjung-malaysia/

[9] (2015) Kindergarten Students, Teachers Evacuated Due to Flood in Puncak Alam. The New Straight Time (NST) http://www.nst.com.my/node/95711

[10] Marincioni, F. (2007) Information Technologies and the Sharing of Disaster Knowledge: The Critical Role of Professional Culture. Disasters, 31, 459-476. http://dx.doi.org/10.1111/j.1467-7717.2007.01019.x 
[11] Preston, J. (2012) Disaster Education. Race, Equity and Pedagogy. Chapter 1: What Is Disaster Education? Sense Publishers, Netherlands. http://dx.doi.org/10.1007/978-94-6091-873-5

[12] (2008) Keseismikan Malaysia (in Malay). Meteorological Department of Malaysia. http://web.archive.org/web/20080624211810/http://www.met.gov.my/malay/pendidikan/seismologi/seismo01.html

[13] (2012) Community Based Disaster Risk Reduction Study: Characteristics of a Safe and Resilient Community. International Federation of Red Cross and Red Crescent Societies, Geneva. https://www.ifrc.org/PageFiles/96986/Final_Characteristics_Report.pdf

[14] Hee, T.F. (2004) Strategic Tripartite Alliance in Establishing a Safe School Programme in Malaysia. School Safety and Security: Lessons in Danger. OECD Publisher.

[15] (2012) Promoting Community-Based Disaster Risk Reduction, Climate Change Adaptation and Emergency Response: For Older People and Other Vulnerable Groups in ASEAN Countries and Japan. [Summary Report] Regional Workshop in Bangkok, Thailand. 15-19 October 2012.

[16] Pribadi, K.S. and Mariany, A. (2008) Implementing Community-Based Disaster Risk Reduction in Indonesia: The Role of Research Institutions and Religions-Based Organizations. https://statebuildingmonitor.files.wordpress.com/2012/01/implementing-community-based-risk-reduction-in-indonesia. pdf

[17] Basher, R. (2013) Science and Technology for Disaster Risk Reduction: A Review of Application and Coordination Needs. UN International Strategy for Disaster Reduction (UNISDR) (Final Report).

http://www.preventionweb.net/posthfa/documents/Science-and-Technology-for-Disaster-Risk-Reduction.pdf 